RASĀYAN J. Chem.

Vol. 14 | No. 2 |672-675| April - June | 2021 ISSN: 0974-1496 | e-ISSN: 0976-0083 | CODEN: RJCABP http://www.rasayanjournal.com http://www.rasayanjournal.co.in

\title{
ANTI-Escherichia coli NON-PATHOGENIC STRAIN ACTIVITY OF COMPLEX COMPOUND BASED ON COPPER(II) AND 2,4,5- TRIPHENYL-1H-IMIDAZOLE
}

\author{
T. H. Sucipto ${ }^{1}$, W. Setyarini ${ }^{2}$, F. Martak ${ }^{3}$ and D. Raharjo ${ }^{2,4, 凶}$ \\ ${ }^{1}$ Institute of Tropical Disease, Universitas Airlangga, Campus C UNAIR, Mulyorejo Surabaya, \\ East Java 60115, Indonesia \\ ${ }^{2}$ Gastroenteritis Study Group, Institute of Tropical Disease, Universitas Airlangga, Campus C \\ UNAIR, Mulyorejo Surabaya, East Java 60115, Indonesia \\ ${ }^{3}$ Department of Chemistry, Institut Teknologi Sepuluh Nopember, Raya ITS Surabaya, \\ East Java 60111, Indonesia \\ ${ }^{4}$ Department of Veterinary Public Health, Faculty of Veterinary Medicine, Universitas Airlangga \\ Campus C UNAIR, Jl. Mulyorejo Surabaya, East Java 60115, Indonesia \\ ${ }^{\bowtie}$ Corresponding Author: dadik_tdc@yahoo.co.id
}

\begin{abstract}
The complex of Copper(II) binding 2,4,5-triphenyl-1H-imidazole ligand is a new copper complex and exhibits therapeutic properties to bacteria. The present observation is focused on anti-Escherichia coli non-pathogenic strain using disc diffusion method. Copper(II)-2,4,5-triphenyl-1H-imidazole complex compound showed anti-Escherichia coli non-pathogenic strain activity with a range of inhibition zone 14.51-17.37 mm and compared with free metal $\mathrm{Cu}$ (II) less reactive with a range of inhibition zone $10.57-27.16 \mathrm{~mm}$, but more no toxic in the Vero cells with $\mathrm{CC}_{50}$ $44.74 \mu \mathrm{g} / \mathrm{ml}$.
\end{abstract}

Keywords: Copper(II), 2,4,5-triphenyl-1H-imidazole, Complex Compound, Antibacterial

RASĀYAN J. Chem., Vol. 14, No.1, 2021

\section{INTRODUCTION}

2,4,5-triphenyl- $1 H$-imidazole plays vital parts for supramolecular congregations since it can give a bidentate $\mathrm{N}$-donor site for chelating with ions of the metal to create bridge ligands, imidazole is a fivemembered ring aromatic compound. It is composed of 3 carbon atoms and 2 nitrogen atoms. ${ }^{1,2,3}$ Imidazole derivatives are known to possess desirable antibacterial, ${ }^{4-8}$ antifungal, ${ }^{6}$ anticancer, ${ }^{9-11}$ and antiviral properties, ${ }^{12,13}$ also 2,4,5-triphenyl-1 $H$-imidazole are exceptionally imperative ligands in organometallic chemistry. Moreover, a few of their complexes bind to DNA. Imidazole antibiotic is pharmaceuticals that are commonly used in human medications and veterinary drugs. ${ }^{14}$ Imidazole 2-aldoximes derivatives were reported anti-Escherichia coli with inhibition zone from $12.4 \pm 0.71$ to $21.8 \pm 0.9 \mathrm{~mm}){ }^{15}$

The importance of metal ions in the vital function of living organisms, from mammalians to bacteria, has been widely recognized. They are incorporated into enzymes and cofactors that are required for various life processes. Copper is a basic following component for numerous organic forms, found in enzyme assortment, counting the copper centers of cytochrome $\mathrm{C}$ oxidase, the $\mathrm{Cu}-\mathrm{Zn}$-containing superoxide dismutase enzyme, and it is the central metal within the oxygen-carrying hemocyanin pigment. ${ }^{16}$ Growth inhibitory effects on common urinary pathogens have been reported, but uropathogenic Escherichia coli (UPEC) are less sensitive to nitric oxide than non-pathogenic strains of Escherichia coli. ${ }^{17}$

In general, the synthesized metal complexes have higher activities of biological to free ligands. Metal complexes excessively aggravate the respiratory process of cells and enhance the fusion of proteins, limiting aiding the development of life forms. In this study, the azomethine linkage $(-\mathrm{C}=\mathrm{N}-)$ within the synthesized complexes displays broad natural action due to expanding the molecules liposolubility in microorganism crossing cell membrane. ${ }^{18}$ 
RASĀYAN J. Chem.

Vol. 14 | No. 2 |672-675| April - June | 2021

The new copper complex has been the significant focus of investigating efforts because too many important biological processes involve metal ions. Recently, complex copper(II) with 2,4,5-triphenyl-1Himidazole exhibits broad therapeutic properties such as anti-breast cancer ${ }^{19}$ and anti-dengue virus type $2 .{ }^{20}$ However, in this experiment we herein report the antibacterial activity within vitro method of copper(II)2,4,5-triphenyl- $1 H$-imidazole complex compound, especially for non-pathogenic strains of Escherichia coli.

\section{Material and Methods}

\section{EXPERIMENTAL}

Copper(II)-2,4,5-triphenyl- $1 H$-imidazole complex compound was synthesized by previous publication ${ }^{14}$ and $\mathrm{CuCl}_{2} \cdot 2 \mathrm{H}_{2} \mathrm{O}$ 99.0\% (Merck, Germany) and bacterial Escherichia coli $\mathrm{ATCC}^{\circledR} 25922^{\mathrm{TM}}$. Dimethylformamide (DMF) (Merck, Germany) was used for the dissolution of the compound and control.

\section{General Procedure}

Antibacterial activity of copper(II)-2,4,5-triphenyl- $1 \mathrm{H}$-imidazole complex compound and $\mathrm{CuCl}_{2} \cdot 2 \mathrm{H}_{2} \mathrm{O}$ were tested against non-pathogenic strains of Escherichia coli in Muller Hinton Agar with disc diffusion method, using $10 \mathrm{ml}$ of suspension containing bacteria $1.5 \times 10^{8} \mathrm{CFU} / \mathrm{ml}$. The discs $(6 \mathrm{~mm}$ in diameter $)$ were added with the $20 \mu \mathrm{l} / \mathrm{disc}$ solutions of the compound. The various concentrations of each compound were $50 \mathrm{mg} / \mathrm{ml}, 75 \mathrm{mg} / \mathrm{ml}, 125 \mathrm{mg} / \mathrm{ml}, 250 \mathrm{mg} / \mathrm{ml}$, and $500 \mathrm{mg} / \mathrm{ml}$. Negative controls were used by the DMF. The plates of inoculation were kept at $37{ }^{\circ} \mathrm{C}$ for $24 \mathrm{~h} .{ }^{21}$ Activity of antibacterial was assessed by measuring the inhibition zone against the test organisms using calipers millimeter scale. Four replications were performed in this test.

\section{Statistical Analysis}

The standard deviation was performed using Microsoft Excel 2010.

\section{RESULTS AND DISCUSSION}

Copper(II)-2,4,5-triphenyl- $1 \mathrm{H}$-imidazole and $\mathrm{CuCl}_{2} \cdot 2 \mathrm{H}_{2} \mathrm{O}$ were tested for anti- Escherichia coli activity with McFarland standard. The activity was resolved to make the use of a disk diffusion method with various concentrations of compound, $50 \mathrm{mg} / \mathrm{ml}, 75 \mathrm{mg} / \mathrm{ml}, 125 \mathrm{mg} / \mathrm{ml}, 250 \mathrm{mg} / \mathrm{ml}$, and $500 \mathrm{mg} / \mathrm{ml}$ in DMF as a solvent. The investigation results were compared with DMF as a negative control and expressed in terms of $\mathrm{mm}$. As the extract concentration increases, the inhibition zone increases. Inhibition zones were shown in Table-1 and the standard deviation curve in Fig.-1.

Table-1: Inhibition Zone of Copper (II)-2,4,5-triphenyl- $1 H$-imidazole and $\mathrm{CuCl}_{2} \cdot 2 \mathrm{H}_{2} \mathrm{O}$ against Escherichia coli

\begin{tabular}{c|c|c}
\hline $\begin{array}{c}\text { Concentration of } \\
\text { Compound }(\mathrm{mg} / \mathrm{ml})\end{array}$ & Inhibitions Zone $(\mathrm{mm})$ \\
\cline { 2 - 3 } & Copper(II)-2,4,5-triphenyl-1H-imidazole & $\mathrm{CuCl}_{2} .2 \mathrm{H}_{2} \mathrm{O}$ \\
\hline 50 & 14.51 & 10.57 \\
\hline 75 & 14.88 & 15.77 \\
\hline 125 & 15.24 & 20.60 \\
\hline 250 & 16.22 & 25.75 \\
\hline 500 & 17.37 & 27.16 \\
\hline DMF & no inhibition zone & no inhibition zone \\
\hline
\end{tabular}

In general, the $\mathrm{CuCl}_{2} .2 \mathrm{H}_{2} \mathrm{O}$ displayed a better inhibitor effect compared to the Copper(II)-2,4,5-triphenyl$1 H$-imidazole complex compound against Escherichia coli with the range of 10.57-27.16 mm. In the previous study, $\mathrm{CuCl}_{2} .2 \mathrm{H}_{2} \mathrm{O}$ effects on Vero cells $\left(\mathrm{CC}_{50}\right)$ up to $5.03 \mu \mathrm{g} / \mathrm{ml}^{22}$ and Copper(II)-2,4,5triphenyl- $1 H$-imidazole up to $44.74 \mu \mathrm{g} / \mathrm{ml}^{20}$ were reported. Free metal has greater polarizability than that complex compound because it contains more electrons and the free metal produced more ions soluble in water. ${ }^{23}$ This effect causes $\mathrm{CuCl}_{2} \cdot 2 \mathrm{H}_{2} \mathrm{O}$ to be more toxic because free metal ions in the medium are more numerous, so it damages the cell wall faster than a complex compound that has high stability such as copper(II)-2,4,5-triphenyl- $1 H$-imidazole.

In a previous study about $\mathrm{Cu}(\mathrm{II})$ complex with $\mathrm{N}$-(5-cloro-2-hydroxyphenyl)-3-methoxy-salicylaldimine ligand was reported to have no activity on Staphylococcus epidermidis. The $\mathrm{Cu}(\mathrm{II})$ complex activity can be clarified with its dissociation in a solvent; the $\mathrm{Cu}(\mathrm{II})$ complex dissociation can be described as an 
RASĀYAN J. Chem.

Vol. 14 | No. 2 |672-675| April - June | 2021

important factor of the antimicrobial activity. ${ }^{24}$.Not only $\mathrm{Cu}(\mathrm{II})$ complex compound with 4-(5nitrofurfuralideamino)-5-mercapto-3-methyl-1,2,4-triazole, but also the complex compound of $\mathrm{Cu}(\mathrm{II})-4$ bromo-2-(1H-imidazo[4,5-f][1,10]phenanthroline-2-yl)phenol was also reported activity of Escherichia coli. $^{25,26}$
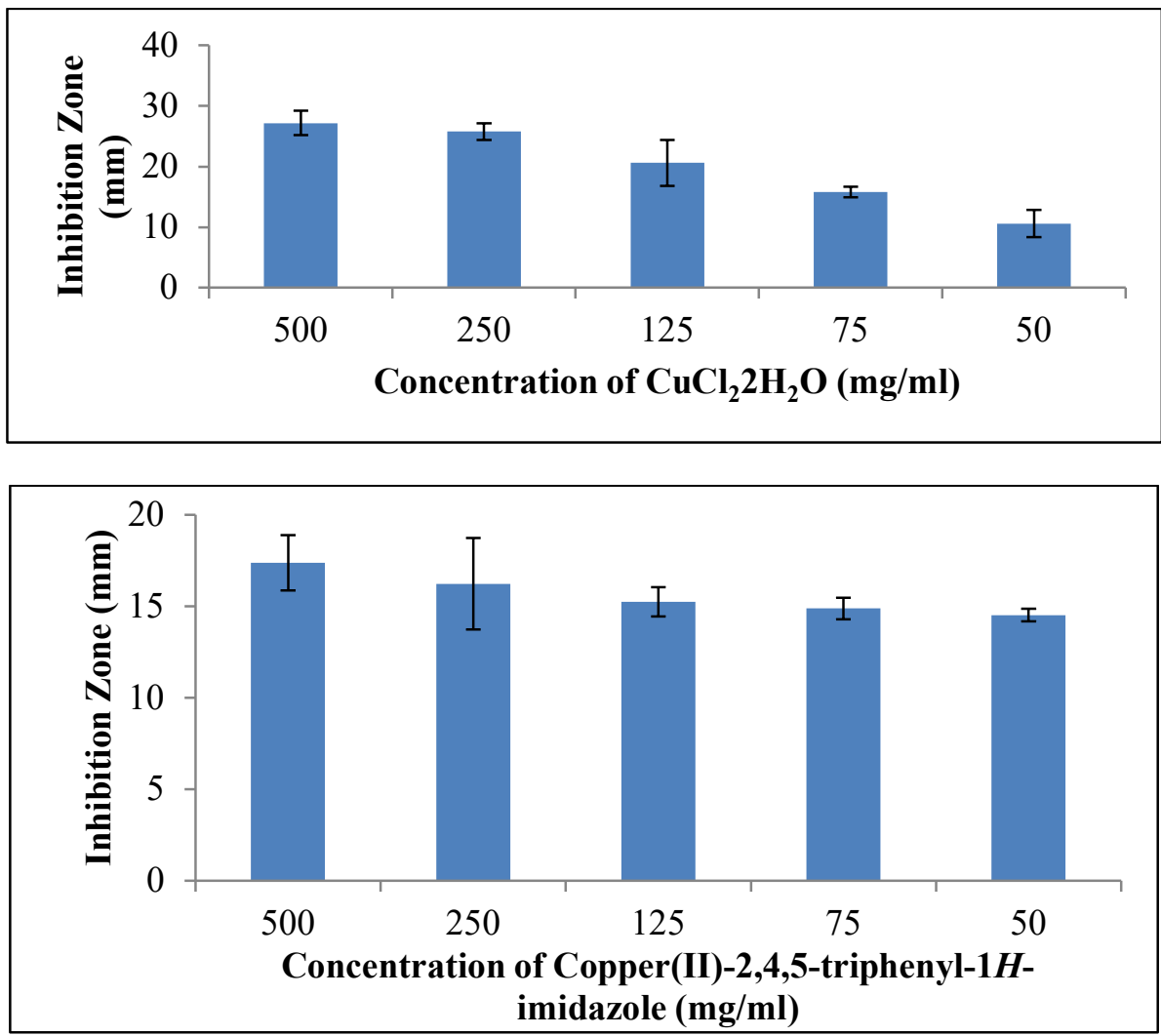

Fig.-1: Standard Deviation of Anti-Escherichia coli Activity of $\mathrm{CuCl}_{2} .2 \mathrm{H}_{2} \mathrm{O}$ and Copper(II)-2,4,5-triphenyl-1 $\mathrm{H}$ imidazole Complex Compound with Various Concentration

Chelation or coordination also reduces the polarity of the ion of metal since the partial sharing of its positive charge with these donor groups and conceivably the $\pi$-electron delocalization inside the total chelate ring framework. Moreover, the process of chelation decreases the central metal atom hydrophilic nature, which is in turn, supports its permeation through the membrane lipid layer, therefore, causing the complex compound to cross the cell wall membrane and increases its microorganism activity. ${ }^{27}$

\section{CONCLUSION}

Copper(II)-2,4,5-triphenyl-1H-imidazole complex compound and $\mathrm{CuCl}_{2} \cdot 2 \mathrm{H}_{2} \mathrm{O}$ showed anti- Escherichia coli activity. $\mathrm{CuCl}_{2} \cdot 2 \mathrm{H}_{2} \mathrm{O}$ performed the highest inhibition zone than Copper(II)-2,4,5-triphenyl- $1 \mathrm{H}$ imidazole complex compound, but it is more toxic to Vero cells. This result is preliminary and is starting for further investigations.

\section{ACKNOWLEDGEMENT}

This research was supported by Lembaga Penelitian dan Inovasi Universitas Airlangga through Hibah Riset Mandat Universitas Airlangga 2019. One of the authors (Mr. T.H. Sucipto) is thankful to Mrs. Virginia Ayu Ferandra and Mrs. Nur Syamsiatul Fajar for being helpful.

\section{REFERENCES}

1. Nagham Mahmood Aljamali, International Journal of Current Research in Chemistry and Pharmaceutical Sciences 1(9), 174(2014)

2. P. Molina, A. Tárraga and F. Otón, Organic \& Biomolecular Chemistry, 10(9), 1711(2012), DOI: $10.1039 / \mathrm{c} 2 \mathrm{ob} 06808 \mathrm{~g}$ 
3. N. P. Singh, K. Kumar, A. Kumar and U. Agarwal, RASĀYAN Journal of Chemistry, 13(1), 215(2020), DOI: 10.31788/RJC.2020.1315571

4. A. K. Jain, V. Ravichandran, M. Sisodiya and R. K. Agrawal, Asian Pacific Journal of Tropical Medicine, 3(6), 471(2010), DOI:10.1016/S1995-7645(10)60113-7

5. M. S. Khan, S. A. Siddiqui, M. S. R. A. Siddiqui, U. Goswami, K. V. Srinivasan and M. I. Khan, Chemical Biology \& Drug Design, 72, (2008), DOI:10.17179/excli2016-710

6. C. Liu, C. Shi, F. Mao, Y. Xu, J. Liu, B. Wei, J. Zhu, M. Xiang and J. Li, Molecules, 19(10), 15653(2014), DOI:10.3390/molecules 191015653

7. C. G. Devkate, K. D. Warad, M. B. Bhalerao, D. D. Gaikwad and M. I. Siddique, Der Pharmacia Sinica, 8, 2 (2017)

8. K. Singh, B. Kumari and A. Sharma, RASĀYAN Journal of Chemistry, 14(1), 29(2021), DOI: $10.31788 /$ RJC.2021.1416108

9. S. Baroniya, Z. Anwer, P. K. Sharma, R. Dudhe and N. Kumar, Der Pharmacia Sinica, 1(3), 172 (2010)

10. I. Ali, M. N. Lone and H. Y. Aboul-Enein, Medicinal Chemistry Communication, 8(9), 1742(2017), DOI: 10.1039/C7MD00067G

11. R. Romagnoli, P. G. Baraldi, F. Prencipe, P. Olivia, S. Baraldi, M. A. Tabrizi, L. C. Lopez-Cara, S. Ferla, A. Brancale, E. Hamel, R. Ronca, R, Bortolozzi, E. Mariotto, G. Basso and G. Viola, Scientific Reports, 6, 26602 (2016), DOI:10.1038/srep26602

12. M. Saudi, J. Zmurko, S. Kaptein, J. Rozenski, J. Neyts and A. V. Aerschot, European Journal of Medicinal Chemistry, 24(87), 529(2014), DOI:10.1016/j.ejmech.2014.09.062

13. S. Ganguly, V. V. Vithlani, R. Kuhu, L. Baskar, P. Mitramazumder, A. Sharon and A. Dev, Acta Pharmaceutica, 61(2), 187(2011), DOI:10.2478/v10007-011-0018-2

14. W. Lee, A. Y. Lin and X. Wang, Desalination and Water Treatment, 52(4-6), 1143(2014), DOI: $10.1080 / 19443994.2013 .826778$

15. M. Skočibušić, R. Odžak, A. Ramić, T. Smolić, T. Hrenar and I, Primožič, Molecules, 23(5), 1212 (2018), DOI:10.3390/molecules23051212

16. A. M. Atria, P. Cortés-Cortés, M. T. Garland, R. Baggio, K. Morales, M. Soto and G. Corsini, Journal of the Chilean Chemical Society, 56(3), 786(2011), DOI:10.4067/S071797072011000300015

17. C. S. Bang, A. Kinnunen, M. Karlsson, A. Önnberg, B. Söderquist and K. Persson, $B M C$ Microbiology, 14, 65 (2014), DOI:10.1186/1471-2180-14-65

18. S. Shukla, Austin Journal of Analytical and Pharmaceutical Chemistry, 3(4), 1077(2016)

19. T. H. Sucipto, H. Setyawati, I. K. Murwani and F. Martak, African Journal of Pharmacy and Pharmacology 12(27), 421 (2018), DOI:10.5897/AJPP2018.4927

20. T. H. Sucipto, S. Churrotin, H. Setyawati, F. Martak, K. C. Mulyatno, I. H. Amarullah, T. Kotaki, M. Kameoka, S. Yotopranoto and S. Soegijanto, African Journal of Infectious Diseases 12(1), 54 (2018), DOI:10.2101/Ajid.12v1S.17

21. J. Singh, A. Jangra, J. Kumar, K. Rani and R. Kumar, RASĀYAN Journal of Chemistry, 13(1), 105 (2020), DOI:10.31788/RJC.2020.1315382

22. T. H. Sucipto, S. Churrotin, H. Setyawati, T. Kotaki, F. Martak and S. Soegijanto, Indonesian Journal of Tropical and Infectious Disease, 6(4), 84 (2017), DOI:10.20473/ijtid.v6i4.3806

23. Y. Liu and M Guo, Molecules, 20(5), 8583(2015), DOI:10.3390/molecules20058583

24. D. Gürbüz, A. Çinarli, A. Tavman and S. B. Tan, Bulletin of the Chemical Society of Ethiopia, 29(1), 75(2015), DOI:10.4314/bcse.v29i1.6

25. K. Singh, Y. Kumar, P. Puri, C. Sharma and K. R. Aneja, Arabian Journal of Chemistry, 10, (Supplement 1), S978(2017), DOI:10.1016/j.arabjc.2012.12.038

26. M. Gomleksiz, C. Alkan and B. Erdem, South African Journal of Chemistry, 66, (2013)

27. Z. H. Chohan, C. T. Supuran and A. Scozzafava, Journal of Enzyme Inhibition and Medicinal Chemistry, 19(1), 79 (2004), DOI:10.1080/14756360310001624939

[RJC-5826/2020] 